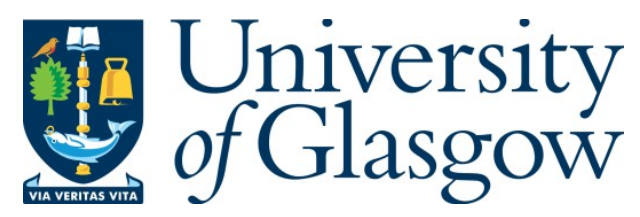

Pennycott, T. W., Grant, D., Leopold, M. F. and Nager, R. G. (2020) Ragworms and other marine food items in the diet of Herring Gulls Larus argentatus breeding on Lady Isle, Firth of Clyde, Scotland. Bird Study, 67(3), pp. 402-408.

(doi: $10.1080 / 00063657.2020 .1869697)$

This is the Author Accepted Manuscript.

There may be differences between this version and the published version. You are advised to consult the publisher's version if you wish to cite from it.

https://eprints.gla.ac.uk/234951/

Deposited on: 26 February 2021

Enlighten - Research publications by members of the University of Glasgow http://eprints.gla.ac.uk 


\section{Ragworms and other marine food items in the diet of Herring Gulls breeding on Lady Isle, Firth of Clyde, Scotland}

Tom W. Pennycott, Browncarrick Drive, Ayr, KA7 4JA, Scotland.

David Grant, University of the West of Scotland, Ayr Campus, Ayr, KA8 0SX, Scotland.

Mardik F. Leopold, Wageningen Marine Research, Ankerpark 27, NL-1781 AG Den Helder, The Netherlands.

Ruedi G. Nager, Graham Kerr Building, IBAHCM, University of Glasgow, G12 8QQ, Scotland. Email of correspondence author: pennycott740@btinternet.com

Larus spp. gulls are opportunistic generalist foragers, at least at the population level (Hunt \& Hunt 1973, Götmark 1984) and their diet is highly adaptable so that it can vary in response to variation in food availability (e.g. Stenhouse \& Montevecchi 1999, Ronconi et al. 2014). A higher proportion of marine resources (marine invertebrates and fish) in their diet can be positively associated with measures of breeding success (Pierotti \& Annett 1991, Annett \& Pierotti 1999, O'Hanlon et al. 2017) and long-term population declines have been associated with dietary shifts away from marine resources (Blight et al. 2015, Hobson et al. 2015, Foster et al. 2017). Thus, knowledge of the marine components of a gull's diet can give insights about changes in the marine foraging environment affecting prey availability and may help to explain changes in the numbers and distribution of gulls.

Pennycott et al. (2020) found that nearly two-thirds of 314 pellets produced by Herring Gulls Larus argentatus breeding on Lady Isle in the Firth of Clyde, southwest Scotland, contained the remains of earthworms; in addition, anthropogenic refuse, cereal and marine items formed 
at least $25 \%$ of the volume of the pellet in $32.2 \%, 30.6 \%$ and $10.2 \%$ of pellets, respectively. Given the importance of marine food to the breeding success in this population (O'Hanlon et al. 2017), here we describe in greater detail the marine food items in the Herring Gull's diet and record estimates of the numbers, combinations and potential calorific values of prey items present in some pellets.

We collected 314 pellets during the incubation period (May) and chick rearing period (June and July, Table 1) in 2018 and 2019. Pellets were collected and analysed as described by Pennycott et al. (2020): briefly, pellets were collected from the rocky periphery of Lady Isle, were broken up in water and passed through a sieve, the contents of the sieve examined using a dissecting microscope (magnification 7-45) and the washings through the sieve examined with a binocular microscope (transmitted light, magnification of 100-400). The presence or absence of different categories of marine food items was recorded, and also whether the combined marine items comprised over $25 \%$ of the volume of the pellet. The presence of marine prey items in the pellets was compared between years and breeding stages using a GLM with binomial error distribution and likelihood ratio tests (R Core Team 2019) and 95\% confidence intervals were calculated using the Jeffreys interval ( $R$ package binom, Dorai-Raj, 2014).

Overall, marine food items were recovered from $24.2 \%$ of pellets, although in only $10.2 \%$ of pellets did such items make up at least $25 \%$ of their volume. In 2018 , more pellets from the chick rearing stage contained marine items than pellets from the incubation stage, whereas the reverse was true in 2019 (GLM with binomial error distribution, $\mathrm{n}=314$ pellets, interaction between breeding stage and year: likelihood ratio test $\chi^{2}{ }_{1}=19.88, p<0.001$; Table 1 ). In 2018, during chick rearing nearly three times as many pellets contained marine prey than during incubation $\left(\chi^{2}{ }_{1}=10.95, p<0.001, n=139\right)$, whereas in 2019 pellets with marine prey were more frequent during incubation than chick rearing $\left(\chi^{2}{ }_{1}=8.98, p=0.003, n=175\right)$. Frequency of pellets with marine prey during incubation was higher in 2019 than in $2018\left(\chi^{2}{ }_{1}=16.49, p<0.001\right.$, $\mathrm{n}=183)$ but in during chick rearing the reverse was the case $\left(\chi^{2}{ }_{1}=5.67, p=0.017, n=131\right)$. This 
reflects variation in the composition of marine prey items found in different years and breeding stages.

Twenty-five pellets ( $8.0 \%$ of all pellets examined) contained one or more amber/brown curved serrated pharyngeal jaws of ragworms of the Family Nereidae (Figure 1), approximately $5 \mathrm{~mm}$ curved length, $1 \mathrm{~mm}$ wide, and with notably square "teeth" typical of the ragworm Eunereis longissima (previously referred to as Nereis longissima) (Witteveen \& Leopold, in prep.). The

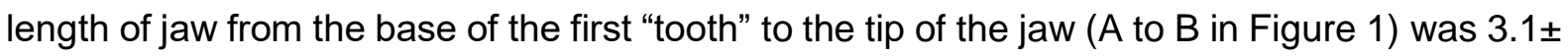
$0.35 \mathrm{~mm}$ (mean \pm standard deviation, $\mathrm{n}=42$ ), indicating an approximate mean ragworm mass of $2.8 \mathrm{~g}$ (Witteveen \& Leopold, in prep.). All pellets containing ragworm jaws were collected during the Herring Gull incubation stage in May, and significantly more pellets contained ragworms in May 2019 than in May 2018 (breeding stage: $\chi^{2}{ }_{1}=30.11$, year: $\chi^{2}{ }_{1}=14.76$, both $p<0.001$, Table 1). Fifteen pellets contained up to four ragworm jaws, five pellets contained between five and twenty jaws, a further four had 31-50 jaws, and one pellet contained over 50 jaws. Lourenço (2007) noted that estimating ragworm consumption by dividing the number of jaws by two would significantly under-estimate the total consumption of ragworms because not all jaws would survive in pairs. It is likely, therefore, that large numbers of ragworms were taken by some Herring Gulls on Lady Isle, especially in May 2019. Although ragworms usually live in burrows in the sediment, out-with the reach of gulls, during the breeding season they become sexually mature and the males form swarms, often swimming near the surface of the sea where they can be taken by seabirds (Courtens et al. 2017). Ragworm spawning is triggered by a rise in sea temperatures after winter and is synchronised to occur when spring tides tend to be especially low at either a full moon or new moon (Bartels-Hardege \& Zeeck 1990). Sample collection dates in May in both years were around the time of spring tides, but sea surface temperatures in spring 2018 were lower than in 2019 (http://climate4you.com/ accessed 14/09/2020) which may have caused a later timing of spawning in 2018 and hence a lower availability of ragworms at the time of sampling in May 2018. 
Ragworms, especially the Harbour or Estuary Ragworm Hediste diversicolor (previously referred to as $N$. diversicolor) are an important part of the diet of many wading birds (GossCustard et al. 1977, Le V. Dit Durrell \& Kelly 1990, De Vlas et al. 1996, Dierschke et al. 1999, Scheiffarth 2001, Lourenço 2007, Duijns et al. 2013), and ragworms have also been recorded in the diet of other groups of coastal and marine birds such as Great Cormorant Phalacrocorax carbo and European Shag P. aristotelis (Barrett et al. 1990, Leopold \& van Damme 2003), Shelduck Tadorna tadorna (Buxton \& Young 1981), Northern Fulmar Fulmarus glacialis (Camphuysen \& van Franeker 1997) and Atlantic Puffin (Harris et al. 2015). However, although recorded as prey items of gulls and terns in the North Sea off The Netherlands, Germany and Belgium (Spaans 1971, Kubetzki \& Garthe 2003, Markones et al. 2009, Camphuysen 2013, Courtens et al. 2017), the Tagus Estuary in Portugal (Moreira 1995), North America (Ambrose 1986) and Japan (Iwamatsu et al. 2007), published records of the consumption of ragworms by gulls in the British Isles appear to be limited. Most relate to Blackheaded Gulls Chroicocephalus ridibundus foraging on H. diversicolor (Vernon 1972, Mudge \& Ferns 1982, Curtis \& Thompson 1985), although Harris (1965) mentioned $H$. diversicolor and N. pelagica as prey items of Herring Gulls in Wales but did not give further details. Thus, the frequent detection of E. longissima in Herring Gull pellets in our study is the first such report from the British Isles and adds to our understanding of the diet of Herring Gulls. Jaws of this species of ragworm have been recovered in large numbers from the faeces of breeding Sandwich Terns Thalasseus sandvicensis from five colonies in Belgium and The Netherlands, mostly in May (Courtens et al. 2017), and from pellets from a mixed gull colony in The Netherlands (Camphuysen 2013); in the latter study, jaws of E. longissima were found in $22 \%$ of pellets from Lesser Black-backed Gulls in the pre-hatching phase and $8 \%$ of Lesser Blackbacked Gull pellets in the post-hatching phase, but in under $1 \%$ of pellets from Herring Gulls. It is unclear whether the detection of E. longissima in pellets from Herring Gulls on Lady Isle represents a change in foraging behaviour in gulls at this location, perhaps in response to a reduction in other marine food resources, or whether earlier studies in the British Isles did not 
detect or report $E$. longissima jaws in gull pellets or faeces because the timing of sample collection missed the short period of ragworm spawning.

Thirty pellets (9.6\%) contained the remains of Langoustines Nephrops norvegicus, including fragments of carapace, legs, chelae (claws), rostra, eyes and antennae. Based on their appearance, Langoustine claws could be identified as being from the upper or lower crushing or cutting claw, enabling an estimation to be made of the minimum number of Langoustines contributing to the pellet. Most pellets contained only one or two Langoustines, but two pellets contained claws from a minimum of four and five Langoustines, respectively, and a combination of Langoustines and fish was detected in seven pellets. The mean length of 17 upper claws recovered from pellets was $17.9 \pm 2.35 \mathrm{~mm}$ (mean \pm standard deviation): although this may have slightly underestimated claw size if they were worn down in the upper digestive tract, this was smaller than the mean of $19.1 \pm 3.01 \mathrm{~mm}$ for 100 upper claws from discarded whole undersized Langoustines $\left(t_{115}=6.87, p<0.001\right)$. The mean size of claws from pellets was also smaller than a mean of $23.2 \mathrm{~mm}$ for 100 upper claws from the cephalothorax of discarded "tailed" Langoustines and a mean of $27.0 \pm 4.47 \mathrm{~mm}$ for 20 upper claws from Langoustines marketed as whole medium-sized Langoustines $\left(\mathrm{t}_{35}=12.16, \mathrm{p}<0.0001\right)$ ( $\mathrm{T}$. Pennycott, reference collection), suggesting that the gulls most likely fed on small undersized whole Langoustines discarded by the local fishery. Significantly more pellets contained Langoustines in the chick-rearing phase than the incubation phase, but the presence of Langoustines did not differ between the two years (breeding stage: $\chi^{2}{ }_{1}=10.98, p<0.001$; year: $\chi^{2}{ }_{1}=0.58, p=0.446$; Table 1). The differences between the two phases may reflect seasonal variation in the landing of Langoustines at the nearby port of Troon (approximately $6 \mathrm{~km}$ from Lady Isle): 200 and 276 tonnes were landed in April/May 2018 and April/May 2019 (incubation phase), respectively, rising to 432 tonnes in June/July 2018 and 375 tonnes in June/July 2019 (chick-rearing phase) (data provided by Marine Scotland Compliance, Edinburgh). 
132 Fish fragments such as vertebrae, ribs, fin rays, bones of the head (dentaries, pre-maxillae, pre-opercula), earstones (otoliths) and pharyngeal teeth were found in 28 pellets $(8.9 \%$ of all examined pellets) and the presence of fish in pellets varied between year and breeding stage (year-by-breeding stage interaction: $\chi^{2}{ }_{1}=7.21, \mathrm{p}=0.007$; Table 1 ). Fish was most frequently present in pellets from the 2019 incubation period but, although less than in 2019, fish was more frequent during chick rearing than incubation in 2018. Where possible, the fish were further identified using descriptions and images provided by Camphuysen \& Henderson (2017). The remains of multiple fish, sometimes of different species, were confirmed in eight individual pellets and may have been present in other pellets with fish remains not identified to the Family level. Otoliths from at least two gadoid fish (codfishes of the Family Gadidae) were identified in four pellets, and one pellet contained evidence of at least one Common Dragonet Callionymus lyra, four wrasse (Family Labridae, most likely Goldsinny Ctenolabrus rupestris) and three gadoids of two different species. Another two pellets each contained the remains of at least two gadoids and one wrasse, and otoliths from at least seven gadoids, most likely Poor Cod Trisopterus minutus, were recovered from an eighth pellet along with the pharyngeal teeth of a wrasse. These are all demersal species and although they have previously been identified in pellets from Herring Gulls breeding in the Firth of Clyde (Nogales et al. 1995, O'Hanlon et al. 2017), our study has highlighted that a single pellet can contain the remains of multiple fish, sometimes of different species or concurrently with Langoustines. Based on measurements of otoliths, pharyngeal teeth and head bones, and compared with reference collections and with figures provided by Camphuysen \& Henderson (2017), the Poor Cod were approximately $10 \mathrm{~cm}$ long, smaller gadoids were under $10 \mathrm{~cm}$, Goldsinny and Common Dragonet approximately $12 \mathrm{~cm}$, and larger gadoids (mostly Haddock Melanogrammus aeglefinus) approximately $17 \mathrm{~cm}$, suggesting that the fish remains found in gull pellets were acquired as discards from the Troon trawler and creel fishery targeting 

pagurus.

Whole or parts of crab legs, claws or fragments of exoskeleton were recovered from 11 pellets maenus, fragments of Velvet Swimming Crab Necora puber were found in one pellet, and in five pellets the species of crab could not be identified. Most pellets appeared to contain fragments from only one crab but one pellet contained claws from at least five Green Shore Crabs. Green Shore Crabs have frequently been found in pellets from Herring Gulls and Lesser Black-backed Gulls in the British Isles and elsewhere (Harris 1965, Spaans 1971, Sibly \& McCleery 1983, Kubetzki \& Garthe 2003, Coulson \& Coulson 2008, Camphuysen 2013), acquired by foraging in the intertidal zone (Kubetzki \& Garthe 2003). Portions of Velvet Swimming Crab have been recorded much less frequently in gull pellets from the British Isles, although they were included (as Portunus puber) by Harris (1965) in the comprehensive list of items consumed by Herring Gulls in Wales, and were found in five out of 43 pellets produced by Lesser or Great Black-backed Gulls on Lady Isle in 2018 (T. Pennycott, unpublished data).

The energetic demands of an adult Herring Gull weighing $1 \mathrm{~kg}$ are estimated to be $980 \mathrm{~kJ} /$ day during the incubation phase, rising to $1220 \mathrm{~kJ} /$ day during brooding and $1430 \mathrm{~kJ} /$ day at the crèche stage (https://ruthedunn.shinyapps.io/seabird fmr calculator/ , accessed 14/11/20).

177 Converting the estimated fish lengths into fish mass (Silva et al. 2013) and with a theoretical calorific value of $3.5-5.0 \mathrm{~kJ} / \mathrm{g}$ (Camphuysen 2013), each Poor Cod might contribute $35-50$ kJ, each Common Dragonet 50 - 70 kJ, each Goldsinny 100 - 145 kJ, and each Haddock 160 $-230 \mathrm{~kJ}$. Although the calorific content of some individual fish may be low, their contribution to the daily energy requirements of the gulls is likely to be significant if, as found in the pellet analysis, multiple fish are consumed. The mean mass of Langoustine consumed by the gulls 
was estimated by weighing whole discarded Langoustines with claws slightly larger than those found in gull pellets, giving a mean of $7.6 \pm 2.76 \mathrm{~g}$ (mean \pm standard deviation, $\mathrm{n}=50$ ). Based on a theoretical calorific value for whole Langoustines of $3.7 \mathrm{~kJ} / \mathrm{g}$ wet weight (Björnsson \& Alvaro 2004), the total calorific value of each consumed Langoustine was only approximately $28 \mathrm{~kJ}$. In addition, Langoustines contain a large amount of poorly digestible chitin in their exoskeleton, reducing their nutritional value. Björnsson \& Alvaro (2004) found that the growth rate of Atlantic Cod Gadus morhua experimentally fed Langoustines was under half of those fed Capelin Mallotus villosus, partly due to the lower percentage of fat and higher levels of ash and chitin in Langoustines, and also because it was more difficult for the Cod to pack their stomachs with Langoustines compared with Capelin because of the tough exoskeleton and appendages of the Langoustines: the same may also be true for Herring Gulls consuming Langoustines. Shore crabs have a fairly low individual calorific value $(<3.5 \mathrm{~kJ} / \mathrm{g}$, Camphuysen 2013) and the size of crab consumed by the gulls is unknown but likely to be small based on the size of claws recovered from the pellets. Individual ragworms have a low calorific value (<3 kJ/g wet weight, Camphuysen 2013), indicating an energy content of only approximately $8 \mathrm{~kJ}$ per ragworm based on an estimated mean mass of $2.8 \mathrm{~g}$, suggesting that their contribution to the total calorific intake of the gulls was low unless consumed in large numbers.

O'Hanlon et al. (2017) cite a number of papers in which seabirds switched to a more nutritious diet when rearing chicks, typically providing more marine items to increase the fat and protein content. However, seasonal changes in availability of different food items will also influence prey selection. Thus, for Herring Gulls breeding on Lady Isle, factors such as rainfall can affect access to earthworms on the mainland (Pennycott et al. 2020), rising sea temperatures in the spring combined with a new or full moon will influence whether gulls can readily obtain ragworms, and seasonal changes in the activities of the local fishing fleet could affect the quantity of fish and Langoustine discards available to foraging gulls.

Comparisons with earlier studies on the diets of Herring Gulls in this part of the Firth of Clyde are difficult due to the different methodologies used. In our study on Lady Isle, marine items 
constituted at least $25 \%$ of the bulk of the pellet in $10.2 \%$ of pellets, similar to the findings of O'Hanlon et al. (2017, Figure 3) who detected marine items in approximately $10 \%$ of gull pellets from Lady Isle in the 2014 breeding season, but less than the figure of approximately $25 \%$ of pellets from the island of Pladda, $27 \mathrm{~km}$ in a westerly direction from Lady Isle (O'Hanlon et al. 2017, Figure 3). When considered as presence/absence of marine items, our study detected marine food items in $24.2 \%$ of pellets examined from the 2018 and 2019 breeding seasons on Lady Isle, compared with Nogales et al. (1995) who found marine food items, mostly fish, in $32.8 \%$ of pellets from adult Herring Gulls during the 1991 breeding season on Ailsa Craig (39 km to the southwest of Lady Isle). The ratio of fish to Langoustine remains also differed: in 1991 on Ailsa Craig, fish remains were found approximately six times more frequently than Langoustine remains, whereas in our study in 2018 and 2019 fish and Langoustines were equally represented. This most likely reflected the change in the nature of commercial fishing in the Firth of Clyde during the 1990s when vessels converted from demersal fishing to targeting Langoustines, to the extent that by 2005 most of the demersal fish catch was bycatch from the Langoustine fishery (Hunter et al. 2015). As a result, discards of larger numbers of undersized demersal fish and highly nutritious offal (liver and intestines) from gutted demersal fish would be replaced by smaller numbers of undersized demersal fish and larger numbers of Langoustines, reducing the nutritional quality available to the gulls.

It is clear from this and other studies that the presence of marine food items and their composition can vary substantially for different dates and sites of sampling, suggesting that breeding Herring Gulls respond to variations in food availability. Therefore, a large number of samples collected over multiple dates, examined using appropriate methodology, will be required before a truly representative assessment of the diet of a Herring Gull population can be made.

\section{Acknowledgements}


We are grateful to SAC Consulting Veterinary Services for access to the Olympus binocular

237 microscope, and to Klaudyna Maniszewska, Rachel Scott, James Scarlett and Roselle Smith 238 for collection of some of the pellets.

\section{References}

Ambrose, W.G.Jr. 1986. Estimate of removal rate of Nereis virens (Polychaeta: Nereidae) from an intertidal mudflat by gulls (Larus spp.). Mar. Biol. 90: 243-247.

Annett, C.A. \& Pierotti, R. 1999. Long-term reproductive output in western gulls: consequences of alternate tactics in diet choice. Ecology 80: 288-297.

Barrett, R.T., Røv, N., Loen, J., \& Montevecchi, W.A. 1990. Diets of shags Phalacrocorax aristotelis and Cormorants $P$. carbo in Norway and possible implications for gadoid stock recruitment. Mar. Ecol. Prog. Ser. 66: 205-218.

Bartels-Hardege, H.D. \& Zeeck, E. 1990. Reproductive behaviour of Nereis diversicolor (Annelida : Polychaeta). Mar.Biol. 106: 409-412.

Björnsson, B. \& Alvaro, M.A.D. 2004. Quality of Nephrops as food for Atlantic Cod (Gadus morhua) with possible implications for fisheries management. ICES J. Mar. Sci. 61:983-991. 
259

260

261

262

263

264

265

266

267

268

269

270

271

272

273

274

275

276

277

278

279

280

281

282

283

Blight, L.K., Hobson, K.A., Kyser, T.K. \& Arcese, P. 2015. Changing gull diet in a changing world: a 150-year stable isotope $\left(\delta^{13} \mathrm{C}, \delta^{15} \mathrm{~N}\right)$ record from feathers collected in the Pacific Northwest of North America. Global Change Biol. 21: 1497-1507.

Buxton, N.E. \& Young, C.M. 1981. The food of the Shelduck in north-east Scotland. Bird Study 28: 41-48

Camphuysen, C.J. 2013. A historical ecology of two closely related gull species (Laridae): multiple adaptations to a man-made environment. PhD thesis. University of Groningen, Groningen.

Camphuysen, C.J. \& van Franeker, J.A. 1997. Notes on the diet of northern fulmars Fulmarus glacialis from Bjùrnùya (Bear Island). Sula 11:1-10.

Camphuysen, C.J. \& Henderson, P.A. 2017. North Sea fish and their remains. Royal Netherlands Institute for Sea Research \& Pisces Conservation Ltd. ISBN-13 978-1-90469065-8.

Coulson, J.C. \& Coulson, B.A. 2008. Lesser black-backed gulls Larus fuscus nesting in an inland urban colony: the importance of earthworms (Lumbricidae) in their diet. Bird Study 55: 297-303.

Courtens, W., Verstraete, H., Vanermen, N., Van de walle, M. \& Stienen, E.W.M. 2017. Faecal samples reveal the diet of breeding adult Sandwich terns Thalasseus sandvicensis in Belgium and the southern part of the Netherlands. J. Sea Res. 127: 182-193. 
Curtis, D.J. \& Thompson, B.A. 1985. Spacing and foraging behaviour of Black-headed Gulls

Larus ridibundus in an estuary. Ornis Scand. 16: 245-252.

287

De Vlas, S.J., Bunskoeke, E.J., Ens, B.J. \& Hulscher, J.B. 1996. Tidal changes in the choice of Nereis diversicolor or Macoma balthica as main prey species in the diet of the Oystercatcher Haematopus ostralegus. Ardea 84: 105-116.

291

Dierschke, V., Kube, J., Probst, S. \& Brenning, U. 1999. Feeding ecology of dunlins Calidris alpina staging in the southern Baltic Sea. I. Habitat use and food selection. J. Sea Res. 42: 49-64.

Dorai-Raj, S. 2014. binom: Binomial Confidence Intervals For Several Parameterizations. R

package version 1.1-1. https://CRAN.R-project.org/package=binom

Duijns, S., Hidayati, N.A. \& Piersma, T. 2013. Bar-tailed godwits Limosa lapponica eat polychaete worms wherever they winter in Europe. Bird Study 60: 509-517.

Foster, S., Swann, R.L. \& Furness, R.W. 2017. Can changes in fishery landings explain 303 long-term population trends in gulls? Bird Study 64: 90-97.

Goss-Custard, J.D., Jones, R.E. \& Newbery, P.E. 1977. The ecology of the Wash. I. Distribution and diet of wading birds (Charadrii). J. App. Ecol. 14: 681-700. 
Götmark, F. 1984. Food and foraging in five European Larus gulls in the breeding season: a comparative review. Ornis Fenn. 61: 9-18.

Grant, D., Robertson, D., Nager, R. \& McCracken, D. 2013. The status of breeding gulls on Lady Isle, Ayrshire. 2012. Scott. Birds 33: 298-307.

Harris, M.P. 1965. Food of some gulls. Ibis 107: 43-52.

Harris, M.P., Leopold, M.F., Jensen, J.-K., Meesters, E.H. \& Wanless, S. 2015. The winter diet of the Atlantic Puffin Fratercula arctica around the Faroe Islands. Ibis 157: 468-479.

Hobson, K.A., Blight, L.K. \& Arcese, P. 2015. Human-induced long-term shifts in gull diet from marine to terrestrial sources in North America's coastal Pacific: more evidence from more isotopes $\left(\delta^{2} \mathrm{H}, \delta^{34} S\right)$. Environmental \& Science Technology 49: 10834-10840.

Hunt, G.L. Jr, \& Hunt, M. 1973. Habitat partitioning by foraging gulls in Maine and Northwestern Europe. Auk 90: 827-839.

Hunter, A., Speirs, D.C. \& Heath, M.R. 2015. Fishery-induced changes to age and length dependent maturation schedules of three demersal fish species in the Firth of Clyde. Fish. Res. 170: 14-23 
Iwamatsu, S., Suzuki, A. \& Sato, M. 2007. Nereidid polychaetes as the major diet of migrating shorebirds on the estuarine tidal flats at Fujimae-Higata in Japan. Zoological Science 24: 676-685.

Kubetzki, U. \& Garthe, S. 2003. Distribution, diet and habitat selection by four sympatrically breeding gull species in the south-eastern North Sea. Mar. Biol. 143: 199-207.

Leopold, M.F. \& van Damme, C.J.G. 2003. Great Cormorants Phalacrocorax carbo and polychaetes: can worms sometimes be a major prey of a piscivorous seabird? Marine Ornithology 31: 83-87.

Le V. Dit Durrell, S.E.A. \& Kelly, C.P. 1990. Diets of Dunlin Calidris alpina and Grey Plover Pluvialis squatarola on The Wash as determined by dropping analysis. Bird Study 37: 44-47.

Lourenço, P.M. 2007. Analysing faecal samples of Ragworm predators: not just a matter of counting mandibles. Ardea 95: 151-155.

Markones N., Guse, N., Hüppop, O., \& Garthe, S. 2009. Unchanging diet in a stable colony: contemporary and past diet composition of black-legged kittiwakes Rissa tridactyla at Helgoland, south-eastern North Sea. Helgol. Mar. Res. 63: 199-206.

Moreira, F. 1995. Diet of Black-headed Gulls Larus ridibundus on emerged intertidal areas in the Tagus Estuary (Portugal): predation or grazing? J. Avian Biol. 26: 277-282 
Mudge, G. P. \& Ferns, P.N. 1982. The feeding ecology of five species of gulls (Aves: Larini) in the inner Bristol Channel. J. Zool._197: 455-461.

Nogales, M., Zonfrillo, B. \& Monaghan, P. 1995. Diets of adult and chick Herring Gulls Larus argentatus argenteus on Ailsa Craig, south-west Scotland. Seabird 17: 56-63.

O'Hanlon, N.J., McGill, R.A.R. \& Nager, R.G. 2017. Increased use of intertidal resources benefits breeding success in a generalist gull species. Mar. Ecol. Prog. Ser. 574: 193-210.

Pennycott, T. W., Grant, D. \& Nager, R.W. 2020. Earthworms in the diet of Herring Gulls Larus argentatus breeding on an off-shore island. Bird Study 67: 131-134.

Pierotti, R. \& Annett, C.A. 1991. Diet choice in the herring gull: constraints imposed by reproductive and ecological factors. Ecology 72: 319-328.

R Core Team (2019). R: A language and environment for statistical computing. R Foundation for Statistical Computing, Vienna, Austria. URL https://www.R-project.org/.

Ronconi, R.A., Steenweg, R.J., Taylor, P.D. \& Mallory, M.L. 2014. Gull diets reveal dietary partitioning, influences of isotopic signatures on body condition, and ecosystem changes at a remote colony. Mar. Ecol. Prog. Ser. 514: 247-261.

Scheiffarth, G. 2001. The diet of Bar-tailed Godwits Limosa lapponica in the Wadden Sea: combining visual observations and faeces analyses. Ardea 89: 481-494. 
379 Sibly, R.M. \& McCleery, R.H. 1983. The distribution between feeding sites of Herring Gulls breeding at Walney Island, UK. J. Anim. Ecol. 52: 51-68.

381

382

Silva, J.F., Ellis, J.R. \& Ayers, R.A. 2013. Length-weight relationships of marine fish collected from around the British Isles. Sci. Ser. Tech. Rep., CEFAS Lowestoft. 150: 109pp.

Spaans, A.L. 1971. On the feeding ecology of the Herring Gull Larus argentatus Pont. in the northern part of The Netherlands. Ardea 55: 73-188.

Stenhouse, I.J., \& Montevecchi, W.A. 1999. Indirect effects of the availability of capelin and 389 fishery discards: gull predation on breeding storm- petrels. Mar. Ecol. Prog. Ser. 184: 303390 307.

Vernon, J.D.R. 1972. Feeding habitats and food of the Black-headed and Common Gulls. Part 2 - Food. Bird Study 19: 173-186

Witteveen, L. \& Leopold, M.F. Handbook of North Sea Polychaete Jaw Identification and 396 Biomass Estimation for Diet Studies. Wageningen Marine Research Report (in prep.), The 397 Netherlands. 